\title{
Microbial diversity in the backarc hot springs of Argentina and its role in biogeochemical cycles
}

\author{
MARTINA CASCONE ${ }^{1}$, KAREN LLOYD ${ }^{2}$, TIMOTHY \\ ROGERS $^{3}$, MAARTEN DE MOOR ${ }^{4}$, MATT SCHRENK ${ }^{5}$, \\ PETER H BARRY ${ }^{6}$, GERDHARD JESSEN ${ }^{7}$, AGOSTINA \\ CHIODI $^{8}$, MATTEO SELCI ${ }^{1}$ AND DONATO \\ GIOVANNELLI ${ }^{9}$ \\ ${ }^{1}$ University of Naples Federico II \\ ${ }^{2}$ The University of Tennessee, Knoxville \\ ${ }^{3}$ University of Tennessee \\ ${ }^{4}$ National University \\ ${ }^{5}$ University of Colorado Boulder \\ ${ }^{6}$ Woods Hole Oceanographic Institution \\ ${ }^{7}$ Austral University of Chile \\ ${ }^{8}$ National University of Salta \\ ${ }^{9}$ Monte Sant'Angelo \\ Presenting Author: martina.cascone1995@gmail.com
}

Subduction zones are critical in recycling of volatiles and elements between the surface and planetary interior and play a key role in climate stability and planetary habitability. Both in the forearc and backarc the lithosphere is affected by the deformation induced by the plate movements, generally favouring faults formations and the widespread origination of deeply-sourced springs, hot or cold, that carry deep fluids and gases to the surface. These fluids and gases originate from the subducting slab as well as from the interaction of the rising fluids and melts with the overlying crust, and generate "hot spots" of microbial diversity and activity driven by the sharp redox, geochemical and often thermal gradients. Given their direct connection with the subsurface, deeply-sourced springs can be used as a window into the deep to understand processes happening at depth. To be able to use deeply-sourced springs as conduits to the subsurface we need to be able to deconvolve the surface signals from the deep subsurface ones. Despite the abundance of studies looking at the microbiology of hot springs globally, there are relatively few studies linking microbial diversity to the underlying geological processes, and especially in the backarc regions information is scarce. Here we present data on the microbial diversity of the deeply sourced springs along the backarc of the volcanic complex of Puna, Argentina, and assess the extent of influence from surface processes of the spring communities. We conclude that surrounding soil and shallow subsurface communities contribute minimally to the diversity of the deeply sourced fluids that thus represent key samples to investigate the deep continental subsurface. 